\title{
Effect of contour ridging on runoff and soil loss
}

\author{
Yusuf M. Mohamoud \\ United States Environmental Protection Agency (USEPA), National Exposure Research Laboratory, \\ 960 College Station Road, Athens Georgia 30605, U.S.A. E-mail: Yusuf@epamail.epa.gov.
}

Accepted 27 June, 2012

\begin{abstract}
Contour ridging is a widely used soil and water conservation practice in Southern Africa. However, in recent years, a number of investigators questioned the effectiveness of contour ridges in controlling surface runoff and soil erosion from smallholder farmers' fields. To be an effective conservation practice, contour ridges must store infiltration excess surface runoff as surface depression storage in furrows between the ridges. In this study, three experimental runoff plots were established in Chilindamaji and six in Kamundi watershed in Malawi. Of the six plots in Kamundi, three had agroforestry contour hedgerows (AF1, AF2, and AF3) and the other three (K1, K2, and K3) had no contour hedgerows. None of the Chilindamaji plots (C1, C2, and C3) had agroforestry contour hedgerows. Hydrologic response analysis of data obtained from the nine runoff plots revealed that plots that retained more water as infiltration and surface depression storage had less runoff and soil erosion. For both sites, the average soil loss rates for the bare, $50 \%$ residue cover, and the contour ridge plots were 115, 66, and 5 ton/ha/year. The average soil loss rates for the three agroforestry plots were 4.2 ton/ha/year. Our results show that $50 \%$ residue cover reduced soil loss as compared to a bare soil, but are not as effective as the contour ridge and the agroforestry contour hedgerow treatments in reducing surface runoff and soil loss.
\end{abstract}

Key words: Contour ridges, infiltration, runoff, soil loss, agroforestry, residue cover.

\section{INTRODUCTION}

Soil erosion by water is a serious environmental problem throughout the worlds' terrestrial ecosystems (Pimentel and Kounang, 1998). Many factors contribute to accelerated soil erosion. Dominant among these factors are improper crop cover management, occurrence of highly erosive rainstorms (Angima et al., 2002), presence of highly erodible soils (Angima et al., 2002), and expansion of cultivated lands to areas with steep slopes (Young, 1999). Increased population pressure on the land and continuous land fragmentation by smallholder farmers are also underlying causes of accelerated soil erosion and land degradation in many parts of Africa (Kalipeni, 1996). According to Saka et al. (1995), annual crops are grown on $98 \%$ of the cultivated land of Malawi. As a result, crop canopy cover is not always well established and a large portion of the annual soil erosion rate occurs on bare soil surfaces between planting time and before crop canopy development.

To control soil erosion and conserve water at the same time, Malawi farmers use a ridge and furrow system known as contour ridging, which stores infiltration excess runoff and minimizes the velocity of surface runoff (Saka et al., 1995). The ridges are typically 20 to $30 \mathrm{~cm}$ high and have intervals of approximately $90 \mathrm{~cm}$. Contour ridging is an effective soil and water conservation practice (Aina et al., 1991), but establishing contour ridges and maintaining broken ridges after intense rainstorms are some of the labor-related concerns that make contour ridging less attractive. Despite its wide spread use, contour ridging has not been adopted in some areas in Malawi. For example, contour ridging has not been adopted by farmers who grow crops on floodplain areas along the shores of Lake Malawi or cultivate land with low infiltration capacity soils or steep slopes.

To drain furrow storage and avoid ridge failure after an intense rainstorm, farmers tend to build ridges that have slight gradients. However, building ridges with slight gradients to drain water stored in the furrows causes serious rill erosion and gully formation (Hagmann, 1996; Herweg and Ludi, 1999). An alternative to building ridges 


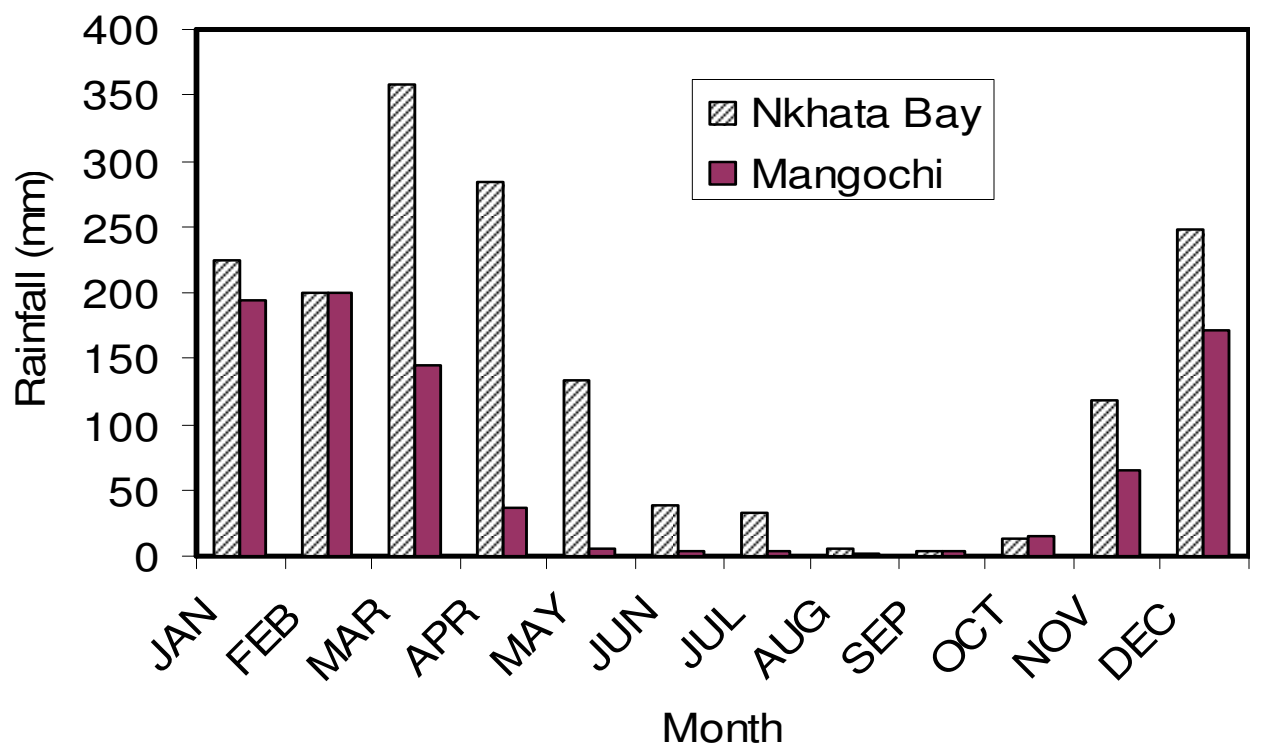

Figure 1. Long-term monthly rainfall for the Chilindamaji and Kamundi watersheds.

with gradients and avoiding rill erosion and gully formation is to build ridges that have correct contour alignment. The use contour ridges with proper alignment may not eliminate ridge breakage, but can limit the occurrence of serious erosion only to periods when intense rainstorms occur. To stabilize ridges and overcome ridge breakage completely, farmers can use permanent vegetated hedgerows and agroforestry practices.

Agroforestry systems that use permanently vegetated hedgerows between crop rows stabilize ridges and provide canopy cover, thus reducing the occurrence of ridge failure by establishing stable ridges and intercepting raindrop impacts (Young, 1989). When $\mathrm{N}$-fixating vegetation is used, a dual benefit of increasing soil fertility and reducing dependence on $\mathrm{N}$ fertilizers is also achieved from agroforestry systems. The objective of this study is to evaluate the effectiveness of traditional contour ridges and agroforestry contour hedgerows in reducing surface runoff and soil loss by evaluating how these conservation practices increase rainfall infiltration and surface depression storage and reduce runoff and soil loss.

\section{MATERIALS AND METHODS}

\section{Study sites}

Experimental runoff plots were established in Chilindamaji (lat. $11^{\circ} 36^{\prime}$ 'S and long. $34^{\circ} 16^{\prime} \mathrm{E}$ ) and Kamundi (lat. 14 $33^{\circ} \mathrm{S}$ and long. $\left.35^{\circ} 13^{\prime} \mathrm{E}\right)$ watersheds located in Nkhata Bay and Mangochi districts of Malawi. The two watersheds are representative of two distinct climatic regions. Chilindamaji represents the high rainfall mountainous region of Northern Malawi, whereas Kamundi represents moderate rainfall and low elevation region of the Mangochi plain of Southern Malawi.

Malawi has two distinct seasons: a seven-month rainy season (November to April) followed by five months of a relatively dry season (May to October) (Figure 1). Figure 1 shows long-term monthly rainfall averages obtained from weather stations located in Nkhata Bay and Mangochi. The long-term mean annual rainfall rates for Chilindamaji and Kamundi are 1657 and $846 \mathrm{~mm}$, respectively. In addition to differences in mean annual rainfall, the two studied watersheds have different soils and topography. The average slope of the Chilindamaji and Kamundi runoff plots are 7.8 and $3.5 \%$, respectively. The Chilindamaji site has sandy clay loam, while the Kamundi site has sandy loam soil and both sites have shallow topsoils with a flow-impeding layer of approximately $30 \mathrm{~cm}$ below the soil surface.

\section{Experimental design}

To evaluate the effectiveness of contour ridging in controlling surface runoff and soil erosion, nine runoff plots were established in two locations in Malawi. Of the nine plots, three of which were in Chilindamaji and other six were in Kamundi (Table 1). The six nonagroforestry runoff plots had bare soil (C1, K1), 50\% crop residue cover $(\mathrm{C} 2, \mathrm{~K} 2)$, and contour ridging $(\mathrm{C} 3, \mathrm{~K} 3)$ treatments. The Kamundi site had also three agroforestry plots with three different contour hedgerow treatments (Figure 2). The contour ridges on the non-agroforestry plots were spaced $90 \mathrm{~cm}$ apart and built to $30 \mathrm{~cm}$ high. Galvanized iron sheets were inserted around the plot boundaries to a depth of $15 \mathrm{~cm}$ to prevent runoff to seep in or out from the plot. The agroforestry plots received contour hedgerow treatments consisting of combinations of maize (Zea mays L.) intercropped with tree and grass species (Table 1).

Throughout the growing season of 1997/1998, rainfall, surface runoff, and soil loss were measured from each runoff plot. Rainfall was measured using manual and recording rain gauges. At the end of each runoff-producing rain event, runoff depth was measured using concrete-lined tanks located at the downslope end of each plot (Figure 2). Water and sediment deposited in the tanks were thoroughly mixed and a representative grab sample was collected for sediment analysis in the laboratory following data collection 
Table 1. Treatment plots tested at the Chilindamaj and Kamundi sites.

\begin{tabular}{llll}
\hline Location & Plot number & Plot size & Treatment description \\
\hline \multirow{3}{*}{ Chilindamaji } & Plot C1 & $10 \times 5 \mathrm{~m}^{2}$ & Bare plot \\
& Plot C2 & $10 \times 5 \mathrm{~m}^{2}$ & $50 \%$ corn residue cover \\
& Plot C3 & $10 \times 5 \mathrm{~m}$ & Contour ridge with corn crop planted \\
& Plot K1 & $10 \times 5 \mathrm{~m}$ & Bare plot \\
\multirow{3}{*}{ Kamundi } & Plot K2 & $10 \times 5 \mathrm{~m}$ & $50 \%$ corn residue cover \\
& Plot K3 & $10 \times 5 \mathrm{~m}$ & Contour ridge with corn crop planted \\
& & & \\
& Plot AF1 & $20 \times 5 \mathrm{~m}$ & Vetiver grass with contour hedgerows \\
& Plot AF2 $^{+}$ & $20 \times 5 \mathrm{~m}$ & Gliricidia with contour hedgerows \\
& Plot AF3 $^{+}$ & $20 \times 5 \mathrm{~m}$ & Gliricidia and vetiver with contour hedgerows \\
\hline
\end{tabular}

${ }^{+}$, Agroforestry plots, which contain contour hedgerows planted with the vegetation listed in the description.

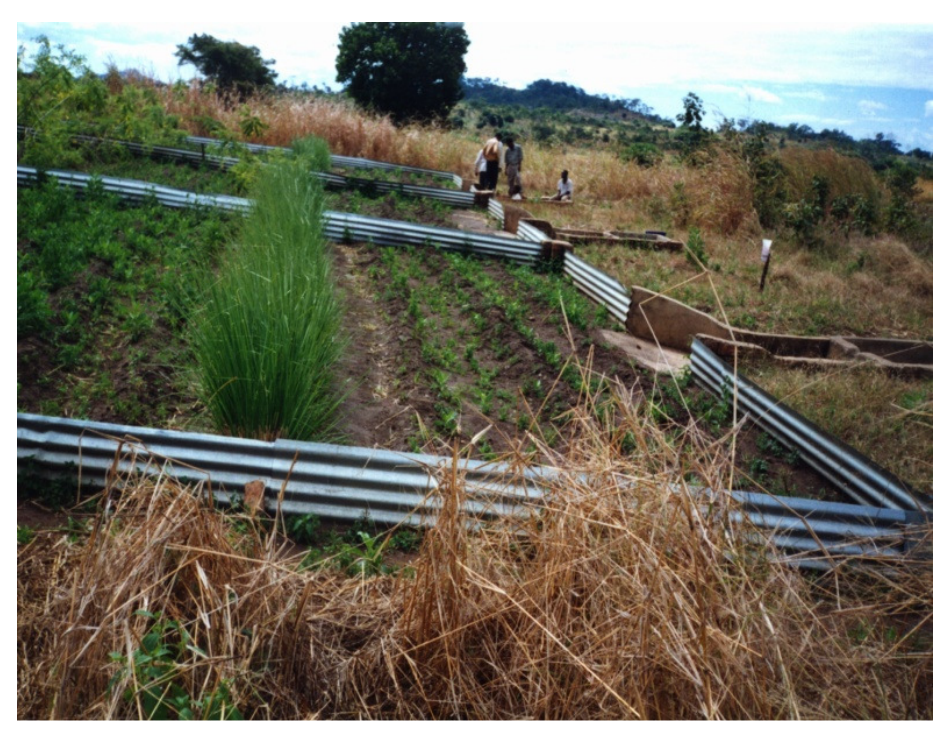

Figure 2. Photograph showing three agroforestry plots with contour hedgerows in Kamundi, Malawi.

protocols available in the literature (Heron, 1990; Hudson, 1983; Kothyari et al., 2004). Soil and nutrient analyses were conducted by Chitedze Agricultural Research Station using standard soil analyses methods (Anderson and Ingram, 1993). Adjacent to the plots at each site, we measured cumulative infiltration depth using a double-ring infiltrometer (Jury et al., 1991).

\section{Estimation of infiltration and depression storage}

To estimate infiltration and depression storage for bare, $50 \%$ residue-covered, and contour-ridged plots, we partitioned rainfall depth into surface depression storage, infiltration, interception, and runoff terms using Equation 1.

$R=P-(I+F+S)$

where $P$ is precipitation depth $(\mathrm{mm}), \mathrm{R}$ is surface runoff depth $(\mathrm{mm})$,
I is interception depth $(\mathrm{mm}), \mathrm{F}$ is infiltration depth $(\mathrm{mm})$, and $S$ is surface depression storage depth $(\mathrm{mm})$.

A storm event, which occurred in Kamundi on December 4, 1997, which produced a rainfall depth of $46.8 \mathrm{~mm}$ over an hour and had maximum $30 \mathrm{~min}$ intensity $\left(\mathrm{l}_{30}\right)$ of $78 \mathrm{~mm} / \mathrm{h}$ was used to demonstrate how infiltration and surface depression storage terms of Equation 1 were determined (Figure 3).

This study assumes that $\mathrm{K} 1$ and $\mathrm{K} 2$ runoff plots had negligible surface depression storage (S), because these plots have no contour ridging. In addition, this study further assumes that interception depth (I) is negligible for plots $\mathrm{K} 1$ and $\mathrm{K} 2$. Using these assumptions, we estimated infiltration depth for K1 and K2 as the difference between rainfall $(P)$ and runoff $(R)$ depths. Because $K 1$, $\mathrm{K} 2$, and $\mathrm{K} 3$ plots have similar soil type and initial moisture content, it is assumed that all the three plots had comparable infiltration depths. Using the calculated infiltration depth, the amount of depression storage was estimated for plot K3 (contour ridged-plot) by subtracting the sum of runoff and infiltration depths from rainfall 


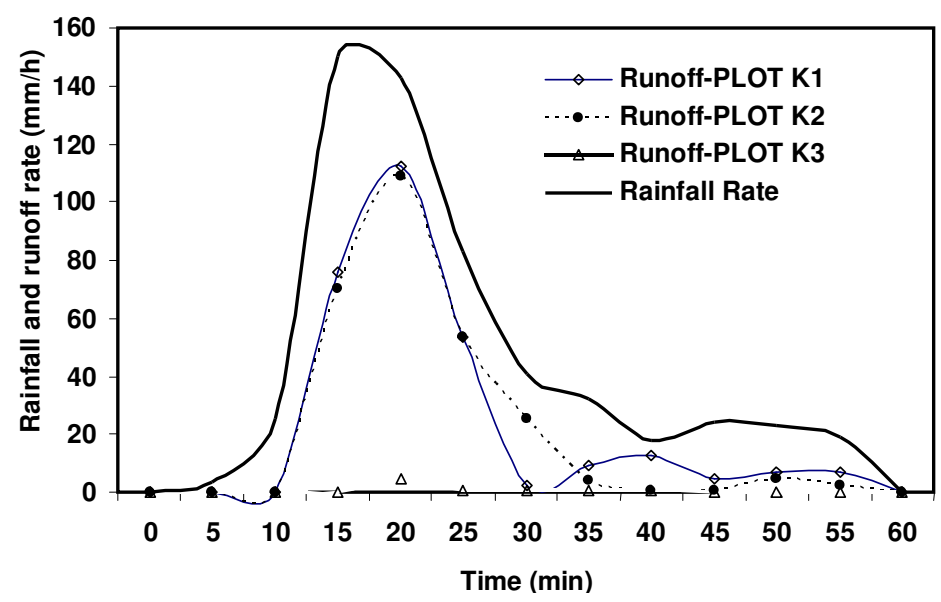

Figure 3. comparisons of rainfall intensity and surface runoff rates generated from small field plots in Kamundi on December 4, 1997.

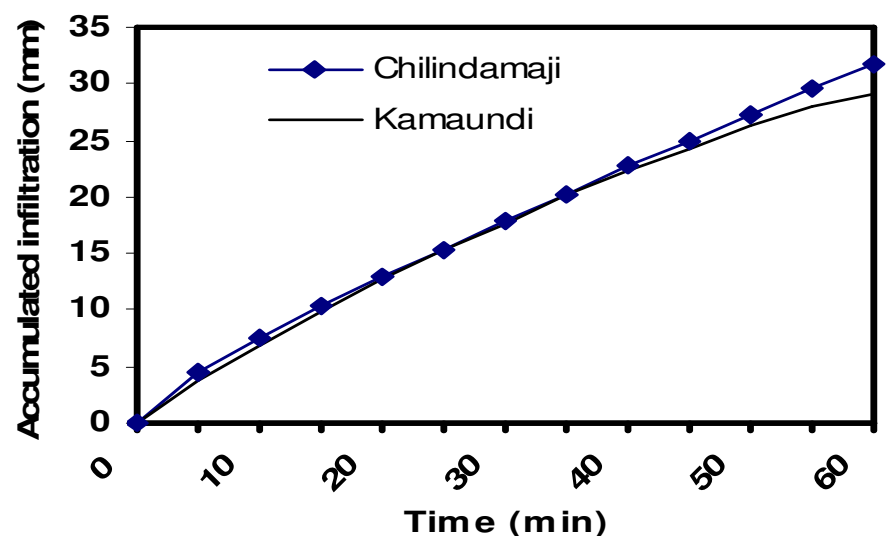

Figure 4. Infiltration depth measured at the experimental sites using a double ring infiltrometer.

depth.

\section{Statistical analyses}

A linear regression analysis was used to examine treatment effects on rainfall and runoff relationships. Equations developed for all the nine treatments are intended to show the fraction of runoff variance that can be explained by rainfall alone. Because soil loss is closed related with runoff, we hypothesize that treatments that control runoff also control soil erosion.

\section{RESULTS}

\section{Effect of contour ridging on infiltration and depression storage}

The bare soil $(\mathrm{C} 1, \mathrm{~K} 1)$ and the $50 \%$ residue cover $(\mathrm{C} 2$, $\mathrm{K} 2$ ) plots had negligible or no surface depression storage. However, the contour ridge $(\mathrm{C} 3, \mathrm{~K} 3)$ plots had relatively high surface depression storage. For the December 4, 1997 storm event, K3 had about $23 \mathrm{~mm}$ or half of the rainfall as surface depression storage, whereas $\mathrm{K} 1$ and $\mathrm{K} 2$ had no depression storage. The estimated infiltration depth for the December 4, 1997 storm was about $22 \mathrm{~mm}$ and was slightly less than the cumulative infiltration depth measured using a double ring infiltrometer (Figure 4). Plots with traditional contour ridges (C3, K3) and agroforestry contour hedgerows (AF1, AF2, AF3) had high infiltration and surface depression storage.

\section{Effect of contour ridging on surface runoff}

A runoff hydrograph analysis of the December 4, 1997 resulted in runoff depth of $23.14,22.46$, and $0.32 \mathrm{~mm}$ for Kamundi plots $\mathrm{K} 1, \mathrm{~K} 2$, and $\mathrm{K} 3$, respectively. This analysis shows that the bare soil (K1) and the $50 \%$ residue cover 

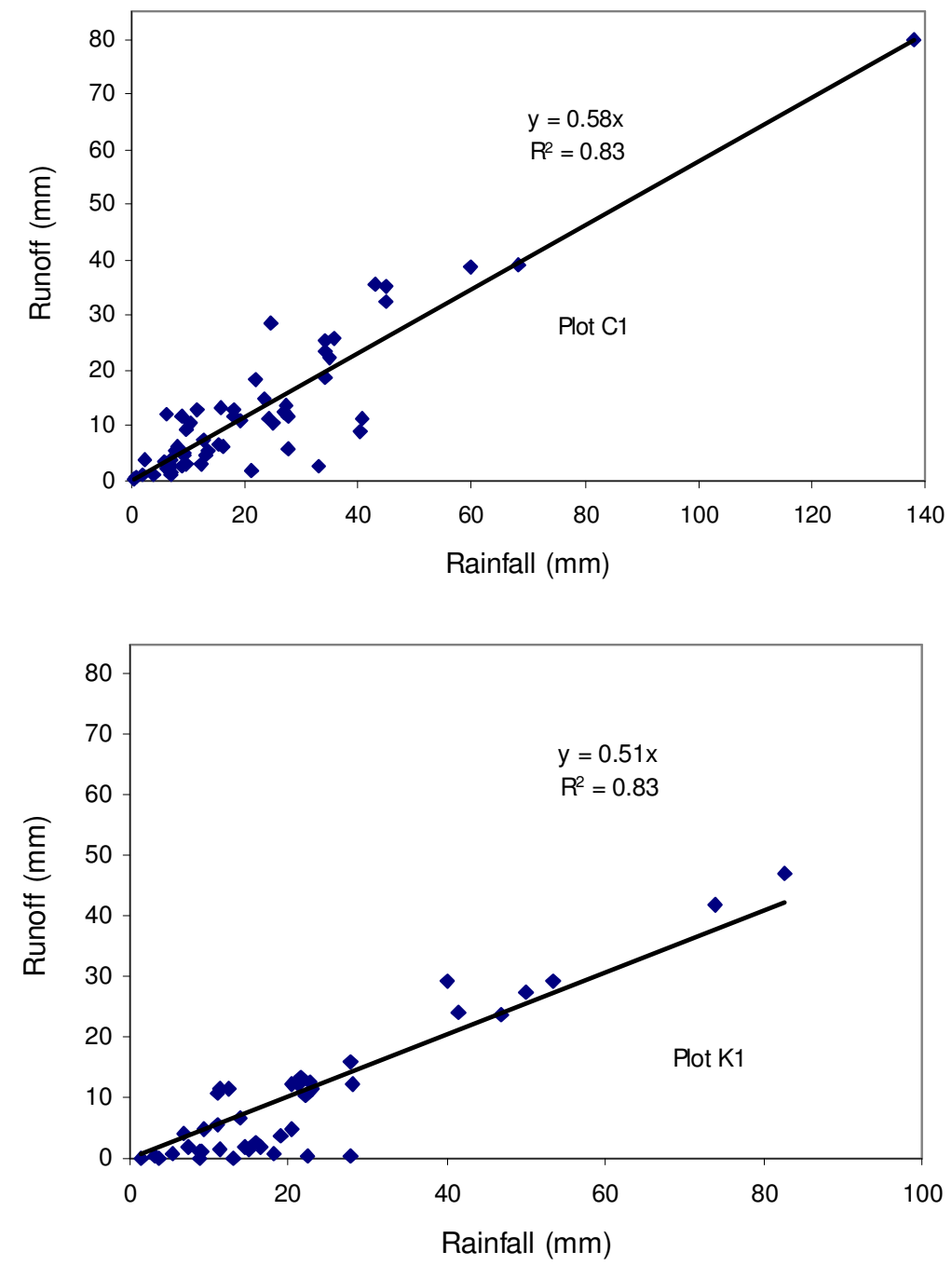

Figure 5. Rainfall and surface runoff relationships of the bare soil treatment at Chilindamaji (C1) and Kamundi (K1) plots.

(K2) had runoff that is equal to half of the rainfall depth. Moreover, linear regression plots that relate runoff to rainfall depth for the bare soil plots ( $\mathrm{C} 1$ and $\mathrm{K} 1)$ show high correlation between rainfall and runoff (Figure 5). Based on the regression plots, on average, about $50 \%$ of the rainfall became runoff. The regression plots of the $50 \%$ residue cover plots (C2, K2) show high correlation between rainfall and runoff (Figure 6). For residue cover plots, on average, about $43 \%$ of the rainfall became runoff. Table 2 also presents similar rainfall-runoff relationships for the bare and residue cover plots in Chilindamaji and Kamundi.

These results show that plots with traditional contour ridges $(\mathrm{C} 3, \mathrm{~K} 3)$ had negligible or no runoff for less intense rain events. The scatters along the $\mathrm{x}$-axis and below the regression line (Figure 7) characterize this response. As an example, $\mathrm{K} 3$ had about $0.32 \mathrm{~mm}$ of runoff for the December 4, 1997 storm. Rainfall-runoff relationship graph of two contour ridge plots (C3, K3) show low correlation (Figure 7). For these two plots, on average, about $10 \%$ of the rainfall became runoff. High runoff was recorded on contour ridge plots only when intense rainstorms occur and when ridges fail and release water stored in the furrows.

\section{Effect of contour ridging on soil loss}

Table 2 shows the comparisons of soil loss data measured from Kamundi and Chilindamaji plots during the 1997/1998 rainy season. At both sites, plots with similar treatments had comparable soil losses. For example, the two bare plots had the highest soil loss followed by the two residue-covered plots, and the traditional contour-ridged and the agroforestry plots with contour hedgerows had the lowest amount of soil loss. 

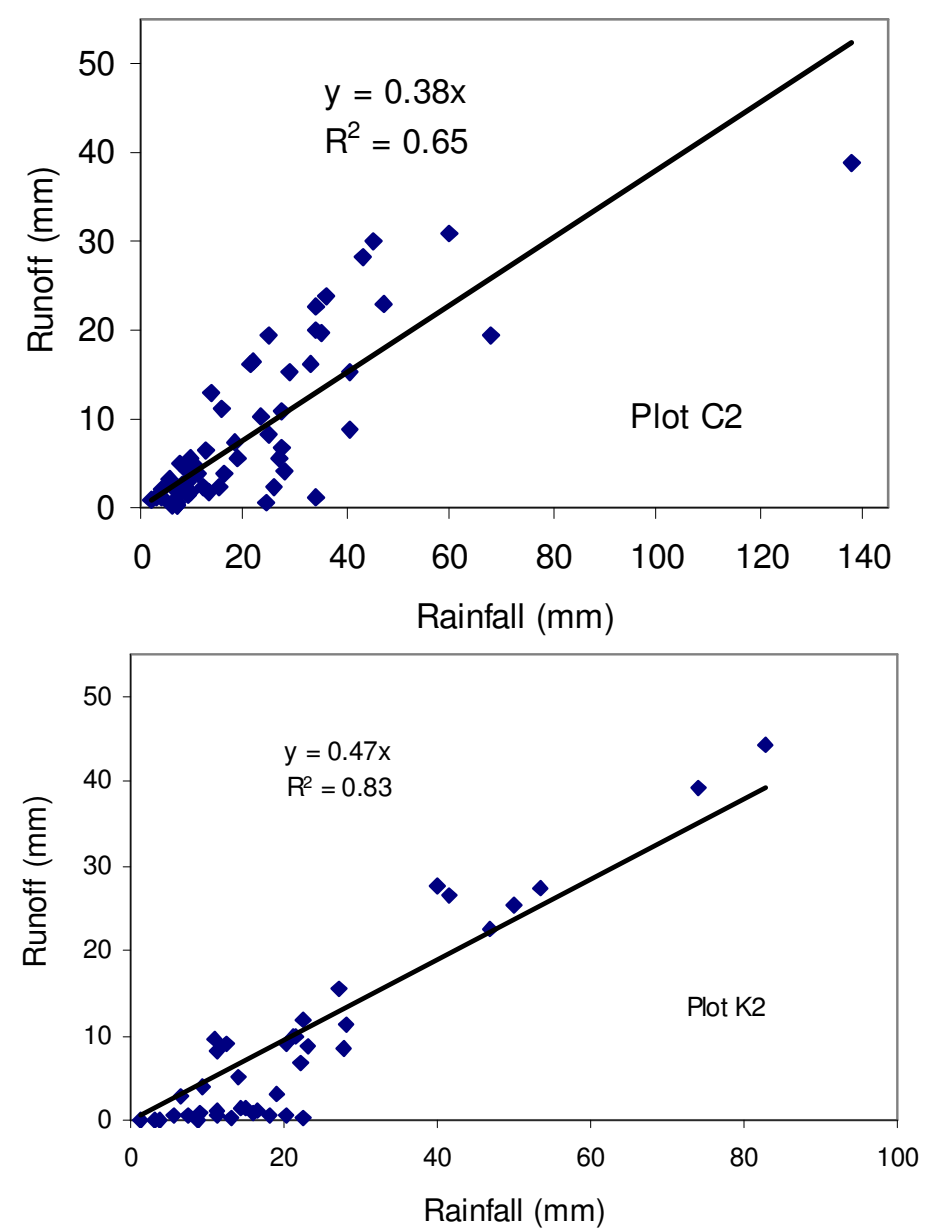

Figure 6. Rainfall and surface runoff relationships of the bare soil treatment at Chilindamaji (C2) and Kamundi (K2) plots.

Table 2. Annual rainfall, runoff, and soil loss from experimental plots.

\begin{tabular}{|c|c|c|c|c|c|}
\hline Study site & Plot name & Treatment & Rainfall (mm) & Runoff (mm) & Soil loss (ton/ha/year) \\
\hline & & & \multicolumn{3}{|c|}{ Plots with no contour hedgerows } \\
\hline & Plot C1 & Bare soil & 1425 & 840 & 129 \\
\hline \multirow{3}{*}{ Chilindamaji } & Plot C2 & $50 \%$ Residual cover & 1425 & 594 & 78 \\
\hline & Plot C3 & Contour ridges & 1425 & 161 & 7 \\
\hline & Plot K1 & Bare soil & 1158 & 475 & 102 \\
\hline \multirow[t]{6}{*}{ Kamundi } & Plot K2 & $50 \%$ Residual cover & 1158 & 454 & 56 \\
\hline & Plot K3 & Contour ridges & 1158 & 34 & 3 \\
\hline & & & \multicolumn{3}{|c|}{ Agro-forestry plots with contour hedgerows } \\
\hline & Plot AF1 & Vetiver grass and contour hedgerows & 1158 & 76 & 2 \\
\hline & Plot AF2 & Gliricidia and contour hedgerows & 1158 & 81 & 3 \\
\hline & Plot AF3 & Gliricidia and vetiver contour hedgerows & 1158 & 112 & 8 \\
\hline
\end{tabular}

Table 3 presents runoff and soil loss data measured from the non-agroforestry plots in Chilindamaji and
Kamundi for ten rain events that produced the highest maximum 30 min intensity. It is noteworthy that these ten 

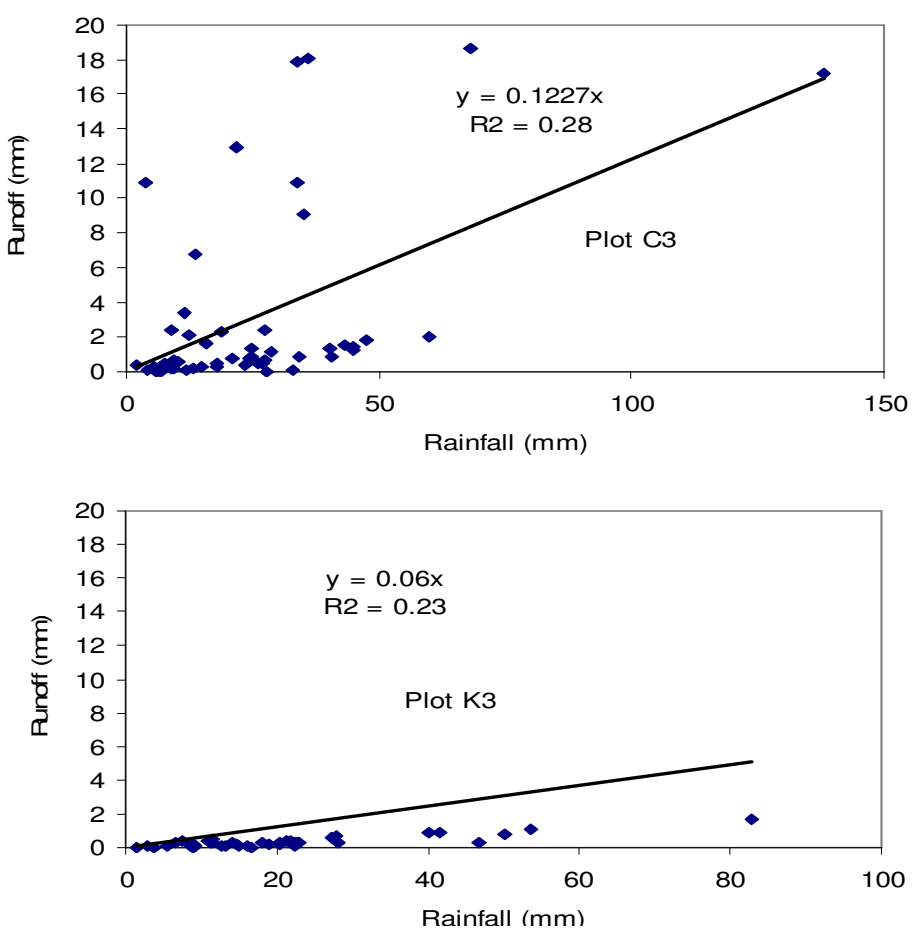

Figure 7. Rainfall and surface runoff relationships of the contour ridge treatment at Chilindamaji (C3) and Kamundi (K3) plots.

Table 3. Rainfall, runoff, and soil loss for the 10 greatest runoff events.

\begin{tabular}{|c|c|c|c|c|c|c|c|c|c|}
\hline \multirow[t]{2}{*}{ Watershed } & \multirow[t]{2}{*}{ Date } & \multirow[t]{2}{*}{ Rainfall (mm) } & \multirow[t]{2}{*}{ Rainfall intensity $\left(I_{30}\right)(\mathrm{mm} / \mathrm{h})$} & \multicolumn{3}{|c|}{ Surface runoff (mm) } & \multicolumn{3}{|c|}{ Soil loss (ton/ha) } \\
\hline & & & & K1 & $\mathrm{K} 2$ & K3 & K1 & $\mathrm{K} 2$ & K3 \\
\hline & 4-Dec-97 & 46.8 & 78.6 & 23.7 & 22.5 & 0.3 & 4 & 4 & 0.2 \\
\hline & 6-Dec-97 & 42.5 & $55.6(\mathrm{~m})$ & 22.8 & 20.8 & 0.5 & 5.5 & 3.6 & 0.1 \\
\hline & 10-Dec-97 & 74 & 89.6 & 41.9 & 39.2 & 20.3 & 7.4 & 4.9 & 0.5 \\
\hline & 10-Dec-97 & 50.1 & 50 & 27.4 & 25.2 & 0.8 & 8.2 & 0.5 & 0.1 \\
\hline & 14-Dec-97 & 53.5 & 42.4 & 29.5 & 27.2 & 1.1 & 4.6 & 4.1 & 0.1 \\
\hline \multirow[t]{12}{*}{ Kamundi } & 24-Dec-97 & 66.7 & $36.8(\mathrm{~m})$ & 37.5 & 35 & 18.5 & 10.2 & 4.7 & 0.3 \\
\hline & 14-Jan-98 & 82.8 & $42.4(\mathrm{~m})$ & 47.3 & 44.4 & 1.7 & 5.5 & 3.7 & - \\
\hline & 28-Jan-98 & 69 & 98.6 & 38.9 & 36.3 & 2.3 & 8.1 & 5.1 & 0.5 \\
\hline & 10-Mar-98 & 41.5 & $80(m)$ & 24.3 & 26.7 & 0.9 & 4.9 & 5.4 & - \\
\hline & 13-Mar-98 & 40 & 50 & 29.2 & 27.7 & 0.9 & 7.8 & 4.3 & - \\
\hline & - & - & - & - & - & Total & 66.3 & 40.2 & 1.8 \\
\hline & & & & $\mathrm{C} 1$ & $\mathrm{C} 2$ & $\mathrm{C} 3$ & $\mathrm{C} 1$ & $\mathrm{C} 2$ & $\mathrm{C} 3$ \\
\hline & 1-Dec-97 & 40.7 & 50 & 11.5 & 8.8 & 0.9 & 8.8 & 2.4 & 0.43 \\
\hline & 8-Dec-97 & 138 & 100 & 79.8 & 38.8 & 17.2 & 33 & 36.4 & 0.43 \\
\hline & 21-De-97 & 68.1 & 39 & 39.4 & 19.3 & 8.5 & 5.4 & 0.5 & 0.2 \\
\hline & 27-Dec-97 & 35.8 & 48 & 25.9 & 23.9 & 18.1 & 4.6 & 1.9 & 0.31 \\
\hline & 5-Jan-98 & 34 & 54.4 & 25.3 & 22.7 & 18 & 1.5 & 3.1 & 0.26 \\
\hline \multirow[t]{6}{*}{ Chilindamaji } & 29-Jan-98 & 32.9 & 49 & 19 & 16.1 & 6.7 & 5.2 & 0.7 & 0.24 \\
\hline & 11-Feb-98 & 59.8 & 23 & 38.8 & 31 & 2 & 5.6 & 0.5 & 0 \\
\hline & 25-Feb-98 & 43.1 & 63 & 35.7 & 28.1 & 1.5 & 4.7 & 0.4 & - \\
\hline & 26-Mar-98 & 47.4 & - & 40 & 22.9 & 1.8 & 2.1 & 0.5 & - \\
\hline & 13-Apr-98 & 44.9 & - & 35.2 & 29.9 & 1.3 & 15.3 & 0.6 & - \\
\hline & - & - & - & - & - & Total & 71 & 46.5 & 1.9 \\
\hline
\end{tabular}

m, Multiple storm events; $I_{30}$, maximum 30 min rainfall intensity. 
Table 4. Chemical and physical composition of sediments eroded from the experimental plots.

\begin{tabular}{|c|c|c|c|c|c|c|c|c|c|c|}
\hline \multirow{2}{*}{$\begin{array}{l}\text { Plot } \\
\text { Plot number }\end{array}$} & \multirow{2}{*}{ Treatment } & \multicolumn{3}{|c|}{ Soil Texture } & \multicolumn{6}{|c|}{ Soil nutrient loss } \\
\hline & & Sand & Silt (\%) & Clay & O.M. & Est. $\mathrm{N}$ & $\mathbf{P}(\mathrm{ppm})$ & $\mathrm{K}(\mathrm{cmol}(+) / \mathrm{kg})$ & $\mathrm{Ca}(\mathrm{cmol}(+) / \mathrm{kg})$ & $\mathrm{Mg}(\mathrm{cmol}(+) / \mathrm{kg})$ \\
\hline Plot K1 & Bare soil & 84.7 & 3 & 12 & 1.2 & 0.6 & 16.5 & 0.1 & 2.3 & 0.5 \\
\hline Plot K2 & $50 \%$ residual cover & 86.6 & 3.1 & 10.4 & 0.7 & 0.1 & 15.8 & 0.1 & 2.9 & 0.6 \\
\hline Plot K3 & Contour ridges & 82 & 6 & 12 & 1.5 & 0.1 & 20.7 & 0.1 & 3.4 & 0.5 \\
\hline Plot C1 & Bare soil & 82 & 5.4 & 12.6 & 1.2 & 0.1 & 0.5 & 0.4 & 11.1 & 1.3 \\
\hline Plot C2 & $50 \%$ residual cover & 81.9 & 5.3 & 12.8 & 1.2 & 0.1 & 0.5 & 0.4 & 0.2 & 1.5 \\
\hline Plot C3 & Contour ridges & 80.8 & 5.5 & 13.8 & 1 & 0.1 & 0.5 & 0.4 & 12.8 & 1.7 \\
\hline Plot AF1 & Vetiver grass contour hedgerows & 76 & 15 & 14 & 3.4 & 0.2 & 60.4 & 1 & 19.5 & 2 \\
\hline Plot AF2 & Gliricidia contour hedgerows & 75 & 8 & 17 & 4.3 & 0.2 & 55.1 & 1 & 24.6 & 3 \\
\hline Plot AF 3 & Gliricidia and vetiver contour hedgerows & 70 & 12 & 18 & 3.4 & 0.2 & 46.3 & 0.6 & 18.9 & 2.5 \\
\hline
\end{tabular}

rain events resulted in approximately 65,72 , and $60 \%$ of the soil loss measured from plots $\mathrm{K} 1, \mathrm{~K} 2$, and $\mathrm{K} 3$, respectively (Table 3). For Chilindamaji, the ten events with the highest intensity resulted in approximately 55,60 , and $27 \%$ of the annual soil loss for C1, C2, and C3, respectively. Table 4 shows chemical and physical composition of sediments that eroded from non-agroforestry and agro-forestry plots in Kamundi. Results show that eroded sediments from the agroforestry plots had higher organic matter, phosphorus, calcium, magnesium, and potassium.

\section{DISCUSSION}

The results of this study show that plots generating high surface runoff had also high soil loss. On average, the Chilindamaji plots had slightly higher soil loss than Kamundi plots. Differences in rainfall depth, duration, intensity, and field slope may contribute to differences in soil loss. In addition, differences in runoff and soil loss between the two sites may be due to differences in weeding techniques and weeding frequency relative to the time when surface runoff producing rainfall events occurred. Despite minor differences in runoff and soil loss between the study sites, plots with similar treatments [for example ( $\mathrm{C} 1$ and $\mathrm{C} 2$ ) or $\mathrm{C} 2$ and $\mathrm{K} 2$ or $\mathrm{C} 3$ and $\mathrm{K} 3$ ] had comparable runoff and soil loss. Our results show that the three agroforestry plots (AF1, AF2, AF3) responded similarly to rainfall, but their response was different from the bare, residue cover, and the traditional contour ridge plots in Kamundi.

The rainfall-runoff relationships for the contourridged plots ( $\mathrm{C} 3$ and $\mathrm{K} 3$ ) and the agroforestry plots with hedgerows (AF1, AF2, and AF3) have relatively low coefficient of determination (Figure 8). A low coefficient of determination in the rainfall-runoff relationship indicates that confounding factors have strong influence on runoff generation. Specifically, a low coefficient of determination indicates that contour ridging is responsible for the low coefficient of determination. Conversely, a linear relationship between rainfall and runoff and high coefficient of determination between rainfall and runoff means that the treatment has little influence on runoff generation from the plot (Figures 6 and 7). Specifically, non-agroforestry plots with no contour ridges had high coefficient of determination (Figures 5 and 6 ).

The ability to store half of the rainfall depth as depression storage indicates makes contour ridging an effective soil and water conservation practice. Its effectiveness, however, varies with storm characteristics, especially rainfall intensity. Contour ridges are effective for storms with high frequency and short duration such as the one that occurred on December 4, 1997. However, ridges break and water stored in the furrows becomes surface runoff in a sudden pulse when intense storms occur. When such storm events occur, contour ridges can become ineffective erosion control practices and cumbersome for smallholder farmers to maintain. Under these conditions, contour hedgerows can stabilize contour ridges and prevent ridge failure. The low correlation between rainfall and runoff and the reduced soil loss measured from the traditional contour ridged plots was indicative of their ability to store infiltration excess runoff as surface depression storage. 

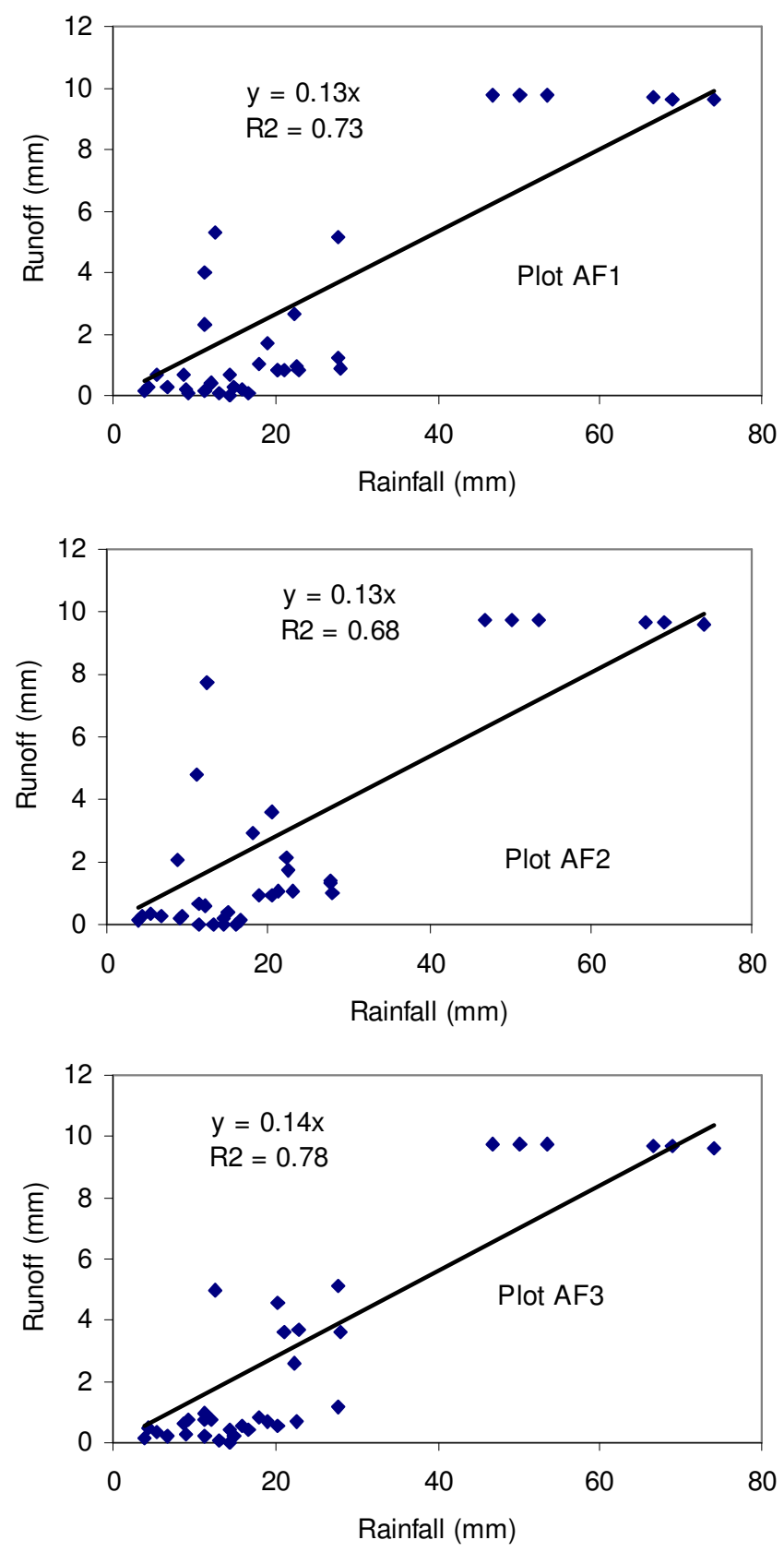

Figure 8. Rainfall and surface runoff relationships of agroforestry plots with contour hedgerows that act as "microdam" emergency spillways.

\section{CONCLUSIONS AND RECOMMENDATIONS}

This study compares surface runoff and soil loss from experimental plots under bare soil, $50 \%$ residue cover, contour ridges, and agroforestry contour hedgerow treatments. The results show that contour ridging effectively controls surface runoff and soil erosion. Compared to bare plots, contour ridging reduced $92 \%$ of the surface runoff and $96 \%$ of soil loss measured at Kamundi. For Chilindamaji, contouring reduced $80 \%$ of the surface runoff and $93 \%$ of the soil loss. Fifty percent residue cover was not effective in controlling surface runoff, but it was slightly effective in reducing soil erosion. When compared to surface runoff measured on a bare plot, the plot with $50 \%$ residue cover had a $4 \%$ surface runoff reduction and a $45 \%$ soil loss reduction. For Chilindamaji, however, $50 \%$ residue cover reduced $35 \%$ of the surface runoff and $46 \%$ of the soil loss.

Overall, contour ridges resulted in reduced surface runoff and soil loss. The 50\% residue cover plots did reduce soil loss, but were inconsistent in reducing surface runoff. In addition to soil fertility related benefits from $\mathrm{N}$-fixating vegetation, contour hedgerows also enhance ridge stability and minimize the incidence of ridge breakage, thus reducing soil erosion and loss. At times when high-intensity storms occur and the rainfall rate exceeds the soil infiltration rate, surface runoff can exceed the depression storage capacity, resulting in contour ridge failure. To overcome this limitation, contour ridges can be reinforced with stabilizing contour hedgerows.

Based on the results of this study, contour ridge plots (C3 and K3) had reduced runoff or negligible amount runoff except when rare rain event occurred. Our recommendation for extension agents is to encourage farmers to control soil erosion collectively by adopting contour ridges that have the correct ridge height, ridge spacing, and correct ridge alignment. Farmers must avoid the use of slight gradients. If all the farmers cultivating on a hillside use slight gradients to drain excess runoff from their field, the resulting concentrated flow can create rill and gulley erosion.

\section{ACKNOWLEDGEMENTS}

This research was supported by a USAID Project, the Malawi Environmental Monitoring Project (MEMP). The author is grateful to all the project staff who participated in the experiment including the University of Malawi students who helped in the data collection effort.

\section{REFERENCES}

Aina PO, Lal R, Roose EJ (1991). Tillage methods and soil and water conservation in West Africa. Soil Tillage Res. 20:165-186.

Anderson JM, Ingram JSI (1993) Tropical Soil Biology and Fertility: A Handbook of Methods, second Ed. CAB International, Wallingford, U.K. p. 221.

Angima SD, Stott DE, O'Neill MK, Ong CK, Weesies GA (2002). Use of Calendar-Napier grass contour hedges to control erosion in central Kenya. Agric. Ecosyst. Environ. 91:15-23.

Hagmann J (1996). Mechanical soil conservation with contour ridges: cure for, or cause of rill erosion - which alternatives. Land Degradation Dev. 7:145-160.

Heron EJ (1990). Collection and preparation of soil and water samples from Cardigan runoff installation, CSIRO Division of Soils Technica, Memorandum. pp. 15.

Herweg K, Ludi E (1999). The performance of selected soil and water conservation measures-case studies from Ethiopia and Eritrea. 
6124 Afr. J. Agric. Res.

Catena 36:99-114.

Hudson NW (1983). Field measurement of soil erosion and runoff, FAO Soil Bulletin, 68. Food and Agriculture Organization, Rome. pp. 139.

Jury WA, Gardner WR, Gardner WH (1991). Soil Physics. Wiley, New York. pp. 143-144.

Kalipeni $E$ (1996). Demographic response to environmental pressure in Malawi. Populat. Environ.. 17: 285-308.

Kothyari BP, Verma PK, Joshi BK, Kothyari UC (2004). Rainfall-runoffsoil and nutrient loss relationships for plot size areas of Bhetagad catchment in Central Himalaya, India. J. Hydrol. 293:137-150.

Pimentel D, Kounang N (1998). Ecology of soil erosion in ecosystems. Ecosystems 1:416-426.
Saka AR, Green RI, Ng'ong'ola DH (1995). Soil management in Subsaharan Africa. Proposed soil management action plan in Malawi. Report to the World Bank. Lilongwe, Malawi. pp. 111.

Young A (1989). Agroforestry for soil conservation. International Center for Research in Agroforestry, Nairobi, Kenya. p. 276.

Young A (1999). Is there really spare land? A critique of estimates of available cultivable land in developing countries. Environ. Dev. Sustainability 1:3-18. 